\title{
ECONOMIC AND LEGAL REVIEW ON MARITAL COMMUNITY AD FAMILY
}

\author{
IbrahimTotic ${ }^{34}$, Mirza Totic ${ }^{35}$
}

\begin{abstract}
The aim of this paper is to look at the basic characteristics of the marital community and family and to formulate differences that exist among them. Legal science considers that marriage is a community regulated by law in which enter, under the same conditions, male and female persons after consciously giving the statements of consent in front of the authorized person, or before the priest of any confession. From once usual manifestation it evolved into a form of life in which the specific relationships (common life, education of the offspring, expansion of family) are regulated by the law. Due to the complexity of legal and social content and moral values in many societies, it is perceived as a monogamous social institution or as a special form of contract of civil law concluded by spouses, otherwise the molecules for the future emergence of extended family. According to all scientific theories, family is a universal human community composed of adult reproductive partners and their offspring. These are usually parents and their children, although they can be supplemented with persons who can be, but not necessarily, blood related with spouses (adoptees, grandfathers, grandmothers, grandchildren). The highest quality of marital community and family are reproductive, social-educational and psychological role.
\end{abstract}

KEY WORDS: marital community, family, offspring, social environment

JEL: J10

UDC: 314.5:330.117

314.5:347.61/.64

COBISS.SR-ID 272229388

\footnotetext{
${ }^{34}$ State university of Novi Pazar, Novi Pazar, Serbia, e-mail: ibrahimtotic @yahoo.com

${ }^{35}$ University of Novi Pazar, Novi Pazar, Serbia, e-mail: mirzatotic@yahoo.com
} 
INTRODUCTION

In modern living conditions one question often arises: is it really the purpose of marriage to create good people, therefore, the expanding of family or, as Najman (1985) says the preparation for a certain misunderstanding, hostility or something that is not foreseen, common or desirable. Unforeseen circumstances can come out from fear of one or both spouses of a common life that represents a novelty and a major social change. As for the fear, the things are totally clear. It does not exist outside of spouses and they are its unique parents (Tempton, 2012), they formed it by thinking: whether they will have luck in their new life, whether they will have offspring and / or have they made the right step and right choice. It is usual for many authors to claim that marriage community gives incentives to spouses to invest in the most valuable things in the world, and these are children-potentially their best friends (Totic, 2017). This confirms the thesis that spouses should invest in health and knowledge of their children which are crown of their marital (extramarital) community.

When it comes to investing in offspring, the primary goal is to avoid sank investments (Pavličić, 2002), which are very common phenomenon in all countries of the world and one of the strong reasons that leads to marital disputes, disagreements, and finally painful separations of spouses. Regardless of the person who observes the investing in children, the conclusion is only one: in each marital union, the economic component has definitely a decisive influence on its flows and outcomes, so no one else, apart from spouses, is asked for an opinion. And if by any case someone else was asked, it would be disputable to answer where did he find the permission and would the latter help him to avoid the emergence of social pathologies. It sends a harsh signal to humanity to stop asking the malapropos question: did God truly created man, because of the fact that only man is capable to create, which is his crowning obligation. He (man) is the only living being who has values (consciousness and conscience) for which it is worth living and who are worthy to be sincerely admired (Smart, 1989). Consciousness is inclination, intuition or judgment that helps to distinguish between good and bad in man about which a moral conclusion can be solved only from values and norms (principles, rules).

Marriage seen as institution represents the object of the family law (Begović, 1961) which observation is not only just legal or normative proving, that it is a pact or a two-sided contract concluded between two spouses on the basis of declaration of will before an authorized person (registrar) in civil proceedings (Ponjavić, 2017) or in front of representative of a religious community. Marriage represents a serious institution and law is a momentous scientific discipline, therefore its goal is to prove, on a scientific basis, by means of norms and legal facts, that the relations of spouses in the community established by marriage contract refer only to them and do not concern anyone (Probst, 2015), as long as under the influence of internal or external factors are not disturbed.

\section{THE CONSISTENCY OF MARITAL COMMUNITY AND FAMILY}

A man, partner or spouse is the perfect being in the physical and spiritual sense. He is the epicenter of many social events, a direct participant in the formation of marital community, and a generator of family expansion seen as the par excellence social cell. In formation of marital community and family expansion he is obliged to confront in some way the changes that have occurred, to explore them and to accumulate the necessary force for the correct understanding of new, but now different, aspects of life. Since being differ, the changes are largely different in form and content, and each of them in its own way affects the new form of life in community. It confirms the thesis that man cannot act alone, survive and create the world according to his wishes. He is the strongest and most effective while acting in a community which defines him to, 
as a social being consciously and readily, makes the right decisions, sets realistic goals and enjoys the results of their reliance. Everyone who wants a harmonious and functional marital community and harmonious family must strive to pursue the same goals: ensure their legal, therefore, formal functioning, the right to own property, the respect for rights of spouses and all family members, the obligation to preserve tradition without which none of them have its full meaning: strengthening, maintaining and increasing human, spiritual and material wealth for the smooth development and certain and secure future. However, this is not always easy to accomplish. Problems such as poverty, conflicts, generational dissolution, disagreement in opinions, interference of the environment, viciousness, envy, unpredictable descendant actions, as well as the lack of capacities necessary for their resolution, often represent the obstacles.

Another important obligation of harmonious marital community, but also a family, is providing the material security for their members that guarantees the existence which many people cannot provide elsewhere, although we must take into account the power of moral capital. With constant development and continuous improvement of marital and family relationships, moral capital reaches its peak as it directly influences their development and improvement. It is desirable the right family to be financially secured and to function completely independently in relation to the environment and global society. There are few such families, and because of misunderstandings in moral values in political and economic system, it is hard to find them even among those 5 percent which are the owners of all forms of world power. In political system (Sjaosi, 2016) the values that contain freedom and equality are far more extensive than those in economic system. Therefore, the marital community is increasingly regarded as an economic union in which membership is provided solely through the possession of money for which value chain (Đuričin, Janošević, Kaličanin, 2011) is experiencing fierce and permanent changes.

Because of the changes many links (until yesterday irreplaceable) from the mentioned value chain have disappeared forever. They are replaced with completely new ones, which in a more modern (but not better) manner determine the firmness, structure and harmony of marital community and propose the plans of expansion, development and further family survival. Because of its frequent rupture and the sense of responsibility for economic security that depends on the spiritual state and rational behavior of economic factors, many spouses and family members do not count on prosperity, since they cannot accept the criteria imposed by the moral law and economic morality (Aristotel, 1992). Thus, the material side has severely defeated the spiritual and has installed irrefutable arguments: that the provision of material existence is the primary goal of every family. Striving to marital community, but also forming a wider family, is influenced by new, modern trends from all over the world, and somehow for a long time it was believed that they come only from the West. The projected paradigm of behavior particularly among the young population: I will materialize myself as a mother (father), but I will never live in a relationship with my husband (wife), since most of all I appreciate personal freedom, has kicked out of the frame for investment in real human values (Yaoming, 2012) the moral side of capital, for which the spirituality is reduced to mere mean. The intelligence attributes such phenomena to globalization. Contemporary authors (Fedotov, 2002, Trkulja, 2003, Stiglitz 2004) use that word to name the destructive processes that have led to a revolution in human behavior. It seems that they have formulated the perfect concept for the enslavement of a modern man in the creation of completely new mechanisms by attacking firstly, his marital union, and then his extended family. This position (Blagojević-Jankovic, 2009) was formed on the basis of experience, that in today's time there are only few marital communities and families who remain together for years, in which govern harmonious spouse, family and interpersonal relations. The experience exists for a long time and does not represent the happiest choice, since it proves already proven, which is the type of social or legal excommunication. 
Getting married is a challenge for many young people compatible with going to a war, with the addition that many future spouses do not actually know against whom will they fight. The formation of marital union, which is known as the posture of the future family, represents such a responsible, demanding, and hard challenge, so many people avoid to confront its real essence. In the lowest position there are those who want to enter into the wrongly called "mixed marriages" which are seen in primitive environments as ignored institutions and unwanted communities. In them, the spouses become the apostates of the people to whom their parents belonged, while their children become objects of contempt because they "do not know who they are, what they are, or to whom they belong to (Perišić, 2012), so what was once a preferred practice, today is been marginalized or not easy to be accepted.

\section{DIFFERENCES BETWEEN MARITAL COMMUNITY AND FAMILY}

It's been believed for a long time that having a harmonious marriage, family and friends means to be forever surrounded by good people, never to be scarce and that anyone who does not have strong material demands have family and friends. They are believed to be at the same time spiritually and materially rich because they are not competing with each other as friends, in who will have a more coherent marital union and who will secure a calmer sea for a ship that sails to the waves of the expansion of family and friendship. Although it has sense, it is still in the contemporary condition hard to maintain the thesis on inalienability of material wealth, which is also debatable for many reasons and in any part of the planet Earth. If material side is not important for the smooth functioning of the marriage and family, why in developed Japan it is inconceivable that young people can have a romance without having secured business success, existence or career? Therefore, the ever-desired money is the axle of the spouse and family relations, and the needs for its providing especially in families with more than one member (especially children) are constant and different.

In addition to money, there are other influences. It is therefore worthwhile to open the aura and find out some hidden reasons that negatively affect the formation, functioning and maintenance of the cohesive marital community. First of all, it refers to the release of future spouses of warped priest thinking, that a harmonious marriage, full of love and concord can endure everything, that it always finds a way to get rid of misery and, to the satisfaction of all its members successfully safeguard the family. In modern conditions, this approach does not offer the required security, on the contrary, it is simply unsustainable and represents the pure utopia. The priests are inclined to claim that all those who serve their closest are prominent and respected, so they are the closest by their character to God (Murphy, 2013), who is the largest servant to all creatures and their greatest friend. This attitude is far from true and therefore unacceptable. It causes frequent and grievous intercourses among lawyers who on the one hand appear with armed facts and ammunition in the form of scientific legal norms and on another side, the theologians, who always and in everything, even in the formation and functioning of marital community, see with great eye the divine hand. The latter have many problems to deal with real intellectuals in this field, not just with lawyers. They are usually pre-grounded, defeated, and beaten up to their feet, since they do not use relevant and tangible evidence, allowing the lawyers to create an environment in which they will completely dominate.

Theologians say (Perić, 2006) that we respect him (God) mostly, as the ruler and emperor, and that as his children we should behave in the way that suits the imperial children. They forget that there are not as many emperors as other's children and that every other child, even though it does not belong to emperor, has parents who will teach him how to behave. To allude on the emperor is not the happiest choice because many spouses were not lucky to be monarchs or to live as part of privileged class in some monarchy. In the world, there are few empires (or other 
forms of rule), in which children of monarchs and rulers were not killed for various reasons. Kaligula declared himself to be God on earth. He raped and killed children, had sexual relations with his sisters, subdued them for money, and raised his horse to the rank of priest ... Tamerlan built in alive people in the walls of the tower, among which there were children ... Russian Emperor Ivan IV got the nickname "Terrible" because he eliminated the main aristocratic families and killed his son ... Mary, the queen of England, ordered burning of hundreds of Protestants and their children, for which she received the nickname "Bloody." The Ottoman sultan Selim I, cruelly executed his four sons, so that his favorite Suleiman can become the ruler. Magda Kvant Gebels, the wife of Nazi Josef Gebels, right before committing suicide (Longerich, 2015), poisoned their six children. Before going to bed, she made them wear a festive dresses and pour the cyanine into their tea. How many unfortunate children just for crazy beliefs?

\section{THE IMPACT OF THE POLLUTERS OF SOCIAL ENVIRONMENT ON MARITAL COMMUNITY AND FAMILY}

Modern world lives the fatal reality which no one has expected and which is particularly present in the past several decades. It did not miss anything, nor on its way it passed around someone or something. It covered the global humankind, all its parts and almost all areas in which are present different human communities and activities. Many values that adorned the marital community (reasonable behavior of spouses, morality, tolerance, understanding, desire for descendants, etc.) and which only a few decades ago were considered to be undoubtedly defined and based on the rules that made them simply inviolable, today not only are questionable, but many are absolutely degraded. In front of all people the social weed was created in the form of narrow, false, selfish and socially unacceptable conditions in which the survival of any, even the marital community or family, is impossible. The marital community does not require creative competition, does not force supremacy over other human communities and does not cause the break of any of them, since its present culture, although floating on the waves of globalization (Totić, 2011), does not have the character of a war formation whose civilian soldiers would push it in the snob. Many people the problems of evil in marital community and family find in the fact that these issues are mainly dealt by humanists, artists and sociologists, so there are no significant scientific research in the true sense of the word. But, this should not be an excuse, and even less the academic approach.

It took a long time for the contemporary marital or family crisis to acquire the right of citizenship among the general public, and it took great courage for the interested parties to recognize it finally. When the crisis began its devastating walk, the authors caused a real stampede in the desire to describe what was not right in many marriages and families, what should be changed, and what, where and when the crisis might have hit. Westermarck (2003) claims that in many serious analyzes of marital and family crises, disagreements and existing conditions, there was nothing left in the fight for their suppression. In other analyzes, most often the spouses were directly declared incapable of living in harmony, for making insufficient efforts for their own existence (Bell, 1997) and for not doing everything in their power for prosperity of their family. Often misunderstandings, intolerance and everything that provokes the creation of problems in common, marital life have caused the communities to take the wrong way instead of right and to neglect its own economic and social function. This has deepened the source from which are being fed up the polluters of social environment, the protagonists of social pathology and obstructionists of harmonious marital, family and all others relations. Otherwise, in science the social pathology is considered to be the collection of negative and general phenomena and events. It is, as Dirkem claims (Milić, 2012) in the widest sense, the science of a complex of facts related to disorders that are socially conditioned, harmful, unacceptable and undesirable. This view of social 
pathology presupposes the existence of a definite scale of socially dangerous events (Milosavljević, 2003) and the search for distance from social conflicts. This is the prove that life reality is very difficult and that it teaches people to understand that every process which deliberates man and humanizes human society (Niče, 2011) in order to be on this (good) side, and not on the other one (bad).

With due respect for the right to business, freedom in different definitions and the obligation to inform the public, it is obvious that all modern media smell on sin, because they directly guide the public, an open call for revenge, homosexuality, lesbianism and prostitution. Bujuklić (2012) correctly stated that the uncritical and unadjusted exposure of a sexual revolution as a paradise for sin on the heart and marriage as a mere form belongs to the history of family law that deals with the question: was it the humanity that abandoned in its distant past the deviant behaviors (promiscuity) only because the blood relationship (consanguinity) degenerated its offspring, or was it, as Morgan (1981) observes, done under the pressure that the survival of its species was seriously questioned? The answer requires time, but it must be admitted that science makes efforts to prove that the only correct way of production of healthy and working people is possible only in harmonious marital communities.

\section{THE POSITION OF CHILDREN IN MARITAL COMMUNITY AND FAMILY}

Starting from the point of view that children are the highest achievement of marital community, the question arises: why are they being abused (Totic, 2018) for such different purposes? Apart from being subjected to brutal sexual assaults, they are forced to work, become the object of trafficking and forced cadavers, because the human body has become the most competitive good (Totić, 2016) in the market of commercial greed, immorality and crime. It is inconceivable that any conscientious person can close eyes to the sexual exploitation of children. Politicians and theologians, who are often the offenders of these incriminating acts, paliently condemn such acts and invite God for help. And those same children, what happens to them? They become the prompt disgrace and care of model and harmonious marital communities and families. They become seed of disruption and one reason more the common life to be replaced by breakups. Parents constantly put pressure on children to go abroad, believing that there are no adequate living conditions in their family circle, that their perspectives are poor and that they cannot hope for a certain future. This suspends the appeal to the family to be unique, to represent the social core, to be a feature of communion or to overcome crises and misfortunes in a complex way or to preserve harmony. Thus, the marital community is getting more and more weakened, and as such has no strength to promote bigger family, not to say to keep it together. Even among this kind of incidents, church dignitaries and incapable politicians humiliate the educational system, by criticizing it for not providing men with knowledge about life, marriage and family (Draškić, 2016). But how then to explain the fact that in the same system many professors, doctors, architects, engineers and church dignitaries were educated and have sailed in marital waters. Considering the fact that there are many factors which do not allow the permanent maintenance and preservation of harmony in the marital community or family, it is necessary the spouses to be more often turned to the world around them (Fairbairn 2011) and to find the best ways and methods that will at least support the sustainable educational line of their successors. 


\section{CONCLUSION}

Modern, therefore, digital age has completely different view on the order of values that make a joint life, which indicates that marriage today is not even close to be as important as it was recently. Legal science, when it comes to marriage, starts from the fact that two people have to make their relationship public, and, if they wish so, to make it legally recognized in order to qualify for certain rights. By entering into marriage, each partner considers that he / she has secured the affection of the other one, that he / she will find interest there, and that will remain with that other person until the end of life. The fundamental need to enter into a marital union is a sense of belonging. During all his life man belongs to someone (parents, friends, group, job), however, the feeling of belonging to a marital partner is probably the strongest one. It is the only real symbol of love that is only possible in marriage which still contains the basic values, at least as long as love exists. Today, marriage is a topic to be avoided, because many people see it as a stumbling stone or stairs difficult to be skipped.

Everybody who thinks that marriage is a surpassed community finds justifications in socioeconomic trends that caused the sexual revolution and made the traditional form of marital union to crash. They see a crucial reason in the equality of spouses, that is, according to the law, the equal status of man and woman, or thanks to her achieved success of becoming equal to man. Macho-marriages represent the thing of the past and have emerged from the framework of tradition. And women, not only that they are not economically dependent on men, they become in other forms of behavior much freer than them. Their freedom causes fear among men, and that is why previous opinions and interpretations of marriage as a form of common life are quite convincing. The additional oil on fire was the moment when the possibility of concluding samesex marriages became reality.

As for the family, in the modern age it loses its primary role. Until recently, it was the basic regulating factor in society, but under the influence of external factors that role was lost, especially in countries that foster a high degree of democracy. The true family plays a fundamental role in organizing and protecting of the interests of its members and ensuring the enjoyment of acquired rights. However, families in which people still continue to make their first social contacts and establish foundations of moral, intellectual, aesthetic and every other upbringing, regardless of the inevitable changes, still do their protective and educational-moral function. Ekerman claims that family is crucial in linking each person to the social system and considers that individual identity needs support from family identity, and that family identity needs support from wider community. In the end, children are the only real reason why most people enter into marital community and expand family. It is a radical change that can be easily endured only by spiritually and morally healthy people. A reasonable man realizes that having children is the most wonderful feeling in the world. 


\section{REFERENCES}

[1] Aristotel. (1992). The Nicomachen ethics, China Social Sciences Publishing House, p. 2.

[2] Begović, M. (1961). Porodično pravo, peto izdanje, Naučna knjiga, Beograd, str. 230.

[3]Bell, D. (1997). „Defining Marriage and Legitimacy”.Current Anthropology. 38 (2): pp. 237- 54.

[4] Blagojević-Janković, M. (2009). Brak za ručak, Pan knjiga, Beograd, str. 210.

[5] Bourdieu, P. (1997). Méditations pascaliennes, Paris, Seuil, coll. « Liber », p. 316.

[6] Bujuklić, Z. (2012). Rimsko privatno pravo, Pravni fakultet Univerziteta u Beogradu, str.432.

[7] Draškić, M. (2016). Porodično pravo, Službeni glasnik. Beograd, str. 303.

[8] Đuricin, D.,Janosevic, S. Kalicanin, Đ. (2011). Menadžment i strategija, Ekonomski fakultet, Beograd, str. 740 .

[9] Fairbairn, D. (2011). Understanding Language: a guide for beginning students of Greek \& Latin, Catholic University of America, p. 190.

[10] Fedotov, A. (2002. Globalizacija-Načela nauke o savremenom miru, Aspekt-Pres, Moskva, str. 18.

[11] Longerich, P. (2015). Goebbels: A Biography Hardcover - Random House; First Edition ,(May 5, 2015), p. 992.

[12] Milić, B. (2012). Emil Dirkem: Od mehaničke do organske odgovornosti, Ka filozofiji,16 maj 2012.

[13] Milosavljević, M. (2003). Devijacija i društvo, Draganić, Beograd, str. 91-247, 271-389.

[14] Murphy, M. (2013). „Cross-National Patterns of Intergenerational Continuities in Childbearing in Developed Countries". Biodemography and Social Biology. 59 (2): pp. $101-126$.

[15] Morgan, H. L. (1981). Drevno društvo, Prosveta. Beograd, str. 508.

[16] Najman, N. V. (1985). Zagađivači socijalne sredine, Zavod za organizaciju, poslovanja i obrazovanje kadrova, Beograd, str. 441.

[17] Niče, F. (2011). S one strane dobra i zla-Genealogija morala, Dereta, Beograd, str. 276.

[18] Pavličić, D. (2002). Konzistentnost izbora metoda višeatributivne analize, Ekonomski anali, Ekonomski fakultet, Univerzitet u Beogradu, Beograd, br. 155, str. 59 - 82.

[19] Perić, D. (2006). Crkveno pravo, Pravni fakultet, Beograd, str. 347.

[20] Perišić, N. (2012). Mješoviti brak u BiH : od poželjnog do prezrenog, mješoviti brak kao kulturna i politička kategorija u savremenoj BiH, Friedrich-Ebert-Stiftung, Sarajevo, str. 156

[21]Ponjavić, Z. (2017). Porodično pravo, 5-to izmenjeno i dopunjeno izdanje, Službeni glasnik. Beograd, str. 456.

[22] Probst, J. (2015). Bračni ugovor, Znanje, Zagreb, str. 295.

[23] Sjaosi, V. (2016). O moralnom kapitalu, Albatros plus, Beograd, 309.

[24] Smart, R. N. (1989). The World's Religions: Old Traditions and Modern Transformations. Cambridge University Press, pp. $10-21$.

[25] Stiglitz, E. J. (2004). Globalizacija i dvojbe koje izaziva, prvo izdanje, Algoritam, Zagreb, str. 303.

[26] Tempton, J. M. (2012). Knjiga životnih zakona-200 večnih duhovnih načela iz celog sveta, Mladinska knjiga, Beograd, str. 502.

[27] Totić, I. (2011). Globalizacija i njen uticaj na savremene integracione procese u svetu, Finansije, časopis za teoriju i praksu finansija, Beograd, br. 1-6, str. 134 - 172.

[28] Totić, I. (2016. Ekonomika zdravstva. Državni univerzitet u Novom Pazaru, Novi Pazar, str. 343. 
[29] Totić, M. Nezaposlenost kao ograničavajući faktor savremenog privrednog razvoja.Međunarodna naučno agrobiznis konferencija MAK 2018, "Evropski put-put uspeha", Kopaonik, 25-26 januar 2018.

[30] Totić, M, Totić, I. (2018). Sinergetsko funkcionisanje humane medicine i medicinskog prava u zdravstvenoj delatnosti, Medicinski glasnik specijalne bolnice za bolesti štitaste žlezde i bolesti metabolizma, Zlatibor, str. 33-47.

[31] Trkulja, J. (2014).,, Globalizacija kao potčinjavanje ili šansa “,(u: Vreme globalizacije, Zbornik, priređivač Miloš Knežević), Dom kulture „Studentski grad“, Beograd, 2003, str. 14.

[32] Westermarck, E. (2003). History of Human Marriage. Kessinger Publishin LLC, p. 340.

[33] Yaoming, G. (2012). Questioning the concept of moral capital. Psihological Trends. 11. (U: Sjaosi, V. O moralnom kapitalu, 2016. p. 159).

\section{Article history:}

- $\quad$ Received 20 September 2018

- $\quad$ Accepted 25 November 2018 